\title{
KOMPOSISI LARVA IKAN DI KAWASAN KOSERVASI MANGROVE DUSUN SENIK, DESA BEDONO, KECAMATAN SAYUNG, DEMAK
}

\author{
Composition of Fish Larvae In The Senik Hamlet Mangrove Conservation Area, \\ Bedono Village, Sayung, Demak \\ Rexa Kurnia Rinaldi, Niniek Widyorini*) dan Pujiono Wahyu Purnomo \\ Program Studi Manajemen Sumberdaya Perairan, Departemen Sumberdaya Akuatik \\ Fakultas Perikanan dan Ilmu Kelautan, Universitas Diponegoro \\ Jl. Prof. Soedarto, SH, Tembalang, Semarang, Jawa Tengah - 50275, Telp/Fax. +6224 7474698 \\ Email : rexa.kurnia21@gmail.com
}

\begin{abstract}
ABSTRAK
Stadia larva merupakan fase pertumbuhan awal ikan. Distribusi dan Kelimpahan larva ikan di Ekosistem Mangrove merupakan proses rekruitmen alami. Kawasan Konservasi Mangrove Dusun Senik Desa Bedono merupakan daerah asuhan dan daerah mencari makan bagi larva ikan, saat ini daerah tersebut terkena abrasi. Hilangnya sebagian besar daratan memberikan pengaruh terhadap distribusi dan kelimpahan larva ikan. Penelitian ini bertujuan untuk mengetahui jenis, kelimpahan, dan sebaran larva ikan di kawasan konservasi mangrove Desa Bedono. Penelitian dilakukan di Kawasan Konservasi Mangrove Desa Bedono bulan September - Oktober 2016. Metode penelitian yang digunakan adalah survei dengan penentuan titik sampling secara purposive. Hasil yang diperoleh jumlah larva ikan yang tertangkap sebanyak $20.320 \mathrm{individu} / 150 \mathrm{~m}^{3}$ yang terdiri dari 12 famili yaitu: Mugilidae $\left(1.120 \mathrm{ind} / 150 \mathrm{~m}^{3}\right)$, Chanidae $\left(20 \mathrm{ind} / 150 \mathrm{~m}^{3}\right)$, Gerreidae $\left(60 \mathrm{ind} / 150 \mathrm{~m}^{3}\right)$, Apogonidae $\left(17.360 \mathrm{ind} / 150 \mathrm{~m}^{3}\right)$, Scatophagidae $\left(40 \mathrm{ind} / 150 \mathrm{~m}^{3}\right)$, Gobiidae $\left(180 \mathrm{ind} / 150 \mathrm{~m}^{3}\right)$, Belonidae $\left(40 \mathrm{ind} / 150 \mathrm{~m}^{3}\right)$, Ambassidae $\left(20 \mathrm{ind} / 150 \mathrm{~m}^{3}\right)$, Lutjanidae $\left(620 \mathrm{ind} / 150 \mathrm{~m}^{3}\right)$, Engraulidae $(60$ ind $\left./ 150 \mathrm{~m}^{3}\right)$, Nemipteridae $\left(40 \mathrm{ind} / 150 \mathrm{~m}^{3}\right)$, dan Oryziatidae $\left(760 \mathrm{ind} / 150 \mathrm{~m}^{3}\right)$. Nilai kelimpahan larva ikan pada titik I sebesar $393 \mathrm{ind} / 150 \mathrm{~m}^{3}$, titik II sebesar $607 \mathrm{ind} / 150 \mathrm{~m}^{3}$, titik III sebesar $800 \mathrm{ind} / 150 \mathrm{~m}^{3}$, titik IV sebesar $1.687 \mathrm{ind} / 150 \mathrm{~m}^{3}$, titik V sebesar $1.633 \mathrm{ind} / 150 \mathrm{~m}^{3}$, titik VI sebesar $607 \mathrm{ind} / 150 \mathrm{~m}^{3}$, titik VII sebesar $235 \mathrm{ind} / 150 \mathrm{~m}^{3}$, titik VIII sebesar 793 ind $/ 150 \mathrm{~m}^{3}$. Berdasarkan indeks morisita, pola sebaran larva ikan adalah acak. Kesimpulan yang dapat diambil adalah famili Apogonidae mendominasi dengan persentase 85,43\%, nilai kelimpahan tertinggi terdapat pada titik IV, dan pola distribusi larva ikan menyebar secara acak yaitu keberadaan spesies tidak memiliki kecenderungan untuk hidup berkoloni dan dapat bertahan hidup di mana saja pada suatu ekosistem.
\end{abstract}

Kata Kunci : Larva ikan; Komposisi; Kelimpahan; Pola Distribusi; Kawasan Konservasi Mangrove

\section{ABSTRACT}

Larval stage is the early growth phase of fish. Distribution and abundance of larval fish in mangrove ecosystem is a natural recruitment process. Mangrove Conservation Area at Senik hamlet Bedono village is the breeding and feeding areas for fish larvae, now the area is damaged by abrasion. The loss of the most mainland affects to the distribution and abundance of fish larvae. This study aims to determine the type, abundance and distribution of fish larvae in mangrove conservation area at Bedono village. The study was conducted in Bedono village Mangrove Conservation Area in September-October 2016. The research method that is used is a survey with purposive sampling point determination. The results obtained, the number of fish larvae caught are 20.320 individuals $/ 150 \mathrm{~m}^{3}$ consisting of 12 families, namely: Mugilidae (1.120 ind $\left./ 150 \mathrm{~m}^{3}\right)$, Chanidae $\left(20 \mathrm{ind} / 150 \mathrm{~m}^{3}\right)$, Gerreidae (60 ind $\left./ 150 \mathrm{~m}^{3}\right)$, Apogonidae $\left(17.360 \mathrm{ind}^{2} 150 \mathrm{~m}^{3}\right)$, Scatophagidae $\left(40\right.$ ind $\left./ 150 \mathrm{~m}^{3}\right)$, Gobiidae $\left(180 \mathrm{ind} / 150 \mathrm{~m}^{3}\right)$, Belonidae $\left(40 \mathrm{ind} / 150 \mathrm{~m}^{3}\right)$, Ambassidae $\left(20 \mathrm{ind}^{2} 150 \mathrm{~m}^{3}\right)$, Lutjanidae $\left(620 \mathrm{ind} / 150 \mathrm{~m}^{3}\right)$, Engraulidae $\left(60 \mathrm{ind} / 150 \mathrm{~m}^{3}\right)$, Nemipteridae $\left(40 \mathrm{ind} / 150 \mathrm{~m}^{3}\right)$, and Oryziatidae (760 ind $\left./ 150 \mathrm{~m}^{3}\right)$. The value abundance of fish larvae in point I is 393 ind $/ 150 \mathrm{~m}^{3}$, in point II is 607 ind $/ 150 \mathrm{~m}^{3}$, in point III is $800 \mathrm{ind} / 150 \mathrm{~m}^{3}$, point $\mathrm{IV}$ is $1.687 \mathrm{ind} / 150 \mathrm{~m}^{3}$, point $V$ is $1.633 \mathrm{ind} / 150 \mathrm{~m}^{3}$, point VI is 607 ind/150m ${ }^{3}$, point VII is 235 ind $/ 150 \mathrm{~m}^{3}$, point VIII is 793 ind $/ 150 \mathrm{~m}^{3}$. Based on morisita index, the distribution pattern of fish larvae is random. The conclusion of this research are family Apogonidae dominates by percentage $85.43 \%$, the highest abundance values is contained in point $I V$, and the distribution pattern of fish larvae randomly spread, means that the species does not live in colonies and can survive anywhere in an ecosystem.

Keywords : Fish Larvae; Composition; Abundance; Distribution; Mangrove Conservation Area

*) Penulis penanggungjawab 


\section{PENDAHULUAN}

Stadia larva merupakan fase pertumbuhan awal pada ikan. Pada fase ini larva mempunyai tingkat mortalitas yang tinggi (Olii, 2003). Menurut Prianto et al. (2013), keberadaan larva didalam perairan sangat penting, sebagai suksesor atau menggantikan peran ikan-ikan dewasa dimasa mendatang. Kondisi tersebut menjadikan wilayah pesisir memilki potensi untuk mendukung kehidupan organisme perairan seperti ikan. Salah satu ekosistem di wilayah pesisir yang memiliki potensi tersebut adalah ekosistem mangrove dimana ekosistem mangrove memiliki fungsi ekologis sebagai daerah memijah (spawning ground), daerah asuhan (nursery ground), dan daerah mencari makan (feeding ground).

Distribusi dan kelimpahan larva ikan di ekosistem mangrove merupakan proses rekruitmen alami. Menurut Claridge et al. (1986) dalam Redjeki (2013) Larva ikan bergantung pada fungsi ekologis mangrove untuk melangsungkan kehidupan karena ekosistem mangrove merupakan produsen primer yang mampu menghasilkan sejumlah besar detritus dari seresah daun dan dahan pohon mangrove dimana dari sana tersedia banyak makanan bagi berbagai biota yang mencari makan pada ekosistem mangrove tersebut.

Dusun Senik Desa Bedono merupakan salah satu desa pesisir di Kecamatan Sayung Kabupaten Demak. Dusun Senik merupakan bagian dari wilayah Desa Bedono yang mengalami degradasi yang sangat luas. Kawasan yang tersisa dari degradasi dari wilayah ini adalah mangrove. Sementara wilayah pendukung atau sekitar telah menjadi perairan yang cukup luas. Berdasarkan hal tersebut memunculkan beberapa pertanyaan mengenai ketersediaan stok benih ikan di kawasan tersebut. Oleh karena itu diperlukan suatu kajian tentang kompoisi larva ikan di kawasan pesisir dan konservasi mangrove Desa Bedono, sehingga dapat memberikan informasi mengenai pengaruh abrasi terhadap kelimpahan larva ikan di Desa Bedono.

Penelitian ini bertujuan untuk mengetahui jenis dan kelimpahan larva ikan di kawasan konservasi mangrove Desa Bedono Demak dan juga untuk mengetahui pola sebaran larva ikan di kawasan konservasi mangrove Desa Bedono Demak. Manfaat yang diharapkan dari kegiatan penelitian ini yaitu dapat memberikan informasi kepada pemerintah dan masyarakat tentang komposisi dan distribusi larva ikan di kawasan konservasi mangrove Desa Bedono Demak, untuk pengelolaan sumber daya alam yang berkelanjutan di masa yang akan datang.

\section{MATERI DAN METODE}

Materi yang digunakan dalam penelitian Komposisi Larva Ikan di Kawasan Konservasi Mangrove Dusun Senik Desa Bedono Kecamatan Sayung Demak adalah sampel larva ikan yang tertangkap menggunakan alat tangkap Scoope Net dari kawasan konservasi mangrove Desa Bedono.

\section{A. Materi}

Alat yang digunakan dalam penelitian lapangan adalah Global Positioning System (GPS) untuk menentukan posisi lokasi penelitian, Scoope Net dengan mesh size $0,5 \mathrm{~mm}$ untuk menjaring larva ikan, botol sampel sebagai wadah larva yang tertangkap, kamera digital untuk dokumentasi, termometer untuk pengukuran temperatur udara dan temperatur air, flowmeter untuk mengukur kecepatan arus, hand refraktometer untuk pengukuran salinitas dengan ketelitian, secchi disk untuk pengukuran kecerahan dan kedalaman, kertas $\mathrm{pH}$ universal untuk pengukuran $\mathrm{pH}$ (derajat keasaman), alat tulis untuk mencatat hasil. Alat yang digunakan di laboratorium untuk identifikasi larva adalah mikroskop stereo, pinset, cawan petri, alat tulis untuk mencatat hasil, kamera digital untuk dokumentasi, dan buku identifikasi sebagai referensi dalam pembanding morfologi larva ikan.

Bahan yang digunakan dalam penelitian ini adalah larva ikan yang tertangkap sebagai sampel untuk diidentifikasi, alkohol $70 \%$ untuk mengawetkan larva ikan.

\section{B. Metode Penelitian}

Metode yang digunakan pada penelitian ini adalah metode survey (Nazir, 1988). Metode yang digunakan dalam penentuan lokasi sampling adalah probability sampling, yaitu teknik pengambilan sampel yang memberikan peluang yang sama kepada setiap anggota populasi untuk menjadi sampel (Gulo, 2002). Penentuan lokasi sampling pada penelitian ini dibagi menjadi 8 titik dimana titik-titik tersebut dianggap mewakili seluruh Kawasan Konservasi Mangrove Desa Bedono. Adapun karakterisitik tiap titik yaitu: Titik I yang langsung berhadapan dengan laut, dengan substrat berpasir serta gelombang air laut yang mempengaruhi titik tersebut. Titik II substrat lumpur, kecepatan arus yang sedang serta mendapat masukan dari laut lepas. Titik III substrat lumpur dan dulu merupakan wilayah tambak. Titik IV substrat pasir berlumpur, arus cukup deras dan merupakan muara sungai. Titik V substrat berpasir serta arus yang cukup deras, titik tersebut merupakan jalan masuk perahu untuk mengantarkan pengunjung ke tempat wisata tracking mangrove. Titik VI substrat lumpur, kecepatan arus sedang serta dekat dengan kawasan wisata tracking mangrove. Titik VII substrat lumpur, kondisi arus tenang dan kedalaman yang dangkal. Titik VIII substrat lumpur, kecepatan arus sedang dan merupakan area penanaman. 


\section{Pengambilan Sampel dan Pengawetan Sampel}

Pengambilan sampel larva ikan dilakukan dengan Scoope Net dengan ukuran tinggi 1 meter dan alas 0,5 meter dan mesh size 0,5 mm. Sampling dilakukan secara pasif dengan mendorong Scoope Net sejauh 30 meter pada setiap titiknya dengan membentuk pola segitiga. Pengambilan sampel dilakukan sebanyak 3 kali pada masing-masing titik dengan interval waktu dua minggu. Setelah sampel didapatkan, dilakukan pengawetan terhadap sampel larva dengan cara penambahan alkohol $70 \%$ ke dalam botol sampel. Bentuk Scoope Net serta ilustrasi pengambilan sampel tersaji pada Gambar 3.

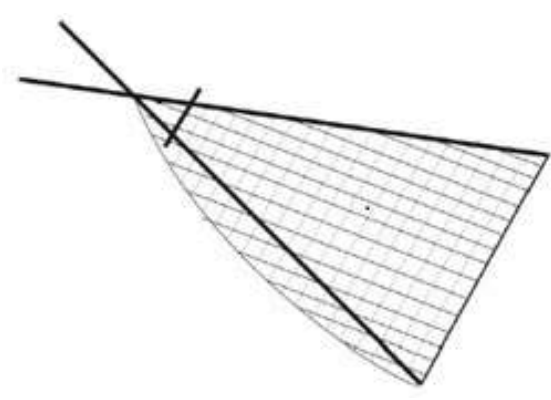

a.

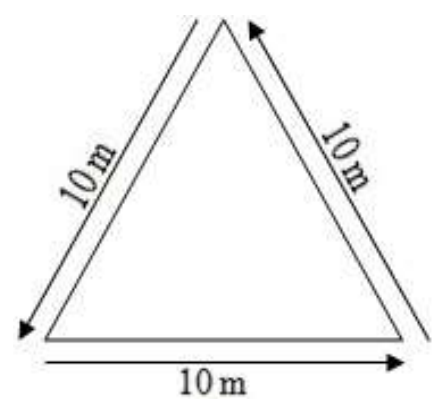

b.

Gambar 1. a. Scoope Net Sebagai Alat Tangkap Larva Ikan, b. Ilustrasi

Teknik Pengambilan Sampel Larva Ikan

\section{Analisis data}

\section{Kelimpahan larva ikan}

Kelimpahan larva ikan yang didefinisikan sebagai banyaknya larva ikan persatuan luas daerah pengambilan contoh dihitung dengan menggunakan rumus modifikasi dari Odum (1993) dalam Riswandha (2015):

Keterangan:

$$
N=\frac{n}{V t s r}
$$

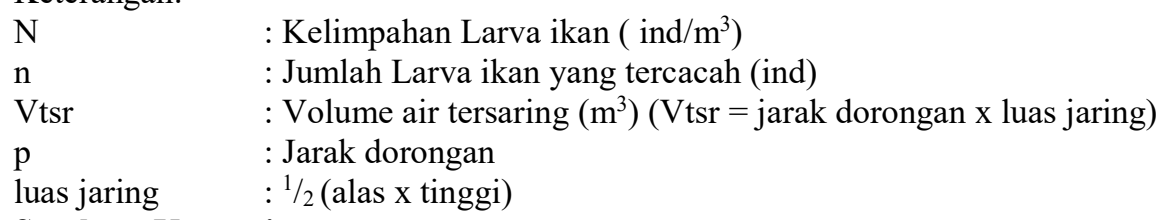

\section{Struktur Komunitas}

Indeks keanekaragaman, keseragaman dan dominansi digunakan untuk mengetahui pengaruh kualitas lingkungan terhadap komunitas larva ikan. Pengaruh kualitas lingkungan terhadap kelimpahan ikan selalu berbeda-beda tergantung pada jenis ikan, karena tiap jenis ikan memiliki adaptasi dan toleransi yang berbeda terhadap habitatnya. Indeks tersebut digunakan untuk memperoleh informasi yang lebih rinci tentang komunitas ikan (Anwar, 2008).

Sampel hasil tangkapan setelah dilakukan identifikasi, perhitungan jumlah individu total setiap spesies dan perhitungan jumlah total spesies, dilakukan analisa data dengan menggunakan rumus indeks keanekaragaman (H'). Indeks keanekaragaman jenis (H') adalah indeks yang menunjukkan banyak tidaknya jenis dan individu yang ditemukan pada suatu perairan.. Keanekaragaman larva ikan dihitung dengan menggunakan indeks Shannon - Wienner diacu dalam Bengen (2000) dalam Anwar (2008), yang dirumuskan sebagai berikut:

$$
\mathrm{H}^{\prime}=-\sum_{i=1}^{s}(\mathrm{pi} \ln \mathrm{pi})
$$

Keterangan:

$$
\begin{array}{ll}
\mathrm{H}^{\prime} & \text { : Indeks keaneragaman Shannon-Wiener } \\
\mathrm{S} & \text { : Jumlah jenis (spesies) } \\
\mathrm{ni} & \text { : jumlah total individu jenis larva ke-i } \\
\mathrm{N} & : \text { jumlah seluruh individu dalam total } \mathrm{n} \\
\mathrm{Pi} & : \frac{\mathrm{ni}}{\mathrm{N}} \text { : sebagai proporsi jenis ke-i }
\end{array}
$$

Kriteria yang digunakan untuk menginterpretasikan indeks keanekaragaman Shannon-Wiener yaitu:

$\mathrm{H}^{\prime}<1 \quad$ : bermakna keanekaragaman larva ikan rendah

$\mathrm{H}^{\prime}=(1-3) \quad$ : bermakna keanekaragaman larva ikan sedang

H'>3 : bermakna keanekaragaman larva ikan tinggi

Data yang diperoleh setelah dilakukan perhitungan indeks keanekaragaman dilanjutkan dengan perhitungan indeks keseragaman. Indeks Keseragaman digunakan untuk melihat keseragaman dari suatu komunitas (Basmi 1999 dalam Furry, 2011) dengan rumus: 
Keterangan:

$$
E=\frac{H^{\prime}}{H \text { maks }} ; \text { dengan } H \text { maks }=\ln S
$$

$$
\begin{array}{ll}
\mathrm{E} & \text { : Indeks Keseragaman } \\
\mathrm{H} & \text { : Indeks Diversitas atau Keanekaragaman } \\
\mathrm{S} & \text { : Jumlah spesies }
\end{array}
$$

Nilai Indeks Keseragaman berkisar antara 0-1. Bila indeks ini mendekati 0 (nol) maka keseragaman antar spesies di dalam komunitas larva rendah, yang menggambarkan kekayaan individu yang dimiliki masing-masing spesies sangat jauh berbeda. Sebaliknya jika mendekati 1 maka keseragaman antar spesies dapat dikatakan merata atau jumlah individu dalam spesies relatif sama (Basmi, 1999 dalam Furry, 2011).

Sampel yang telah di lakukan perhitungan indeks keanekaragaman dan indeks keseragaman, maka hal tersebut dapat mengisyaratkan adanya dominasi suatu spesies terhadap spesies lain. Indeks dominasi digunakan untuk memperoleh informasi mengenai jenis ikan yang mendominasi pada suatu komunitas pada tiap habitat indeks dominansi yang dikemukakan oleh Simpson yaitu (Ludwig dan Reynold, 1988 dalam Anwar 2008):

Keterangan:

$$
\mathrm{C}=\sum_{i=1}^{\mathrm{s}} \mathrm{pi}^{2}
$$

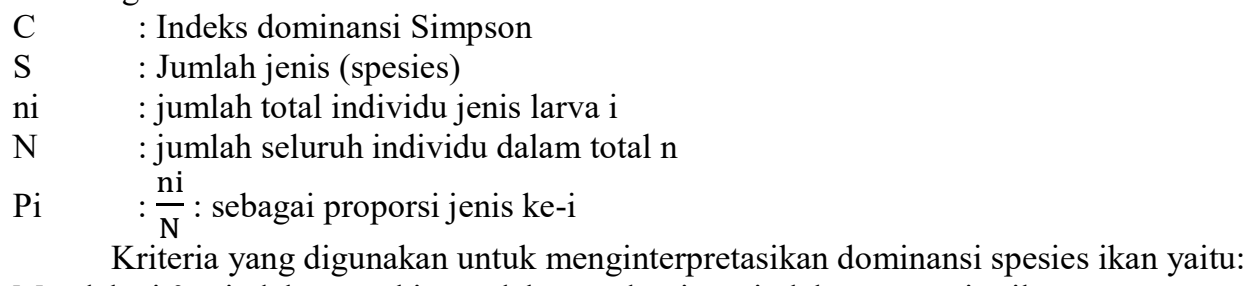

Mendekati $0=$ indeks semakin rendah atau dominansi oleh satu spesies ikan.

Mendekati 1 = indeks besar atau cenderung dominansi oleh beberapa spesies ikan.

\section{Pola distribusi}

Pola penyebaran larva ikan dalam penelitian ini ditentukan dengan menggunakan indeks morisita (I $\delta$ ). Indeks ini tidak dipengaruhi oleh stasiun pengambilan contoh dan sangat baik untuk membandingkan pola pemencaran populasi (Brower et al., 1990 dalam Anwar, 2008). Rumus yang dipergunakan adalah:

Keterangan:

$$
\mathrm{I} \delta=\mathrm{n} \frac{\sum \mathrm{Xi}^{2}-\mathrm{N}}{\mathrm{N}(\mathrm{N}-1)}
$$

I $\quad$ : indeks distribusi morisita

$\mathrm{N} \quad$ : jumlah seluruh individu dalam total $\mathrm{n}$

$\mathrm{N} \quad$ : jumlah seluruh stasiun pengambilan contoh

$\sum \mathrm{Xi}^{2} \quad$ : kuadrat jumlah larva jenis i per stasiun untuk total $\mathrm{n}$ stasiun

Nilai indeks morisita yang diperoleh diinterpretasikan sebagai berikut:

I $\delta<1 \quad$ : pemencaran individu cenderung acak

$\mathrm{I} \delta=1 \quad$ : pemencaran individu bersifat merata

I $\delta>1$ : pemencaran individu cenderung berkelompok.

Pelaksanaan Penelitian

Penelitian dilaksanakan pada bulan September sampai November 2016. Lokasi sampling pada penelitian tersaji pada Gambar 2. 


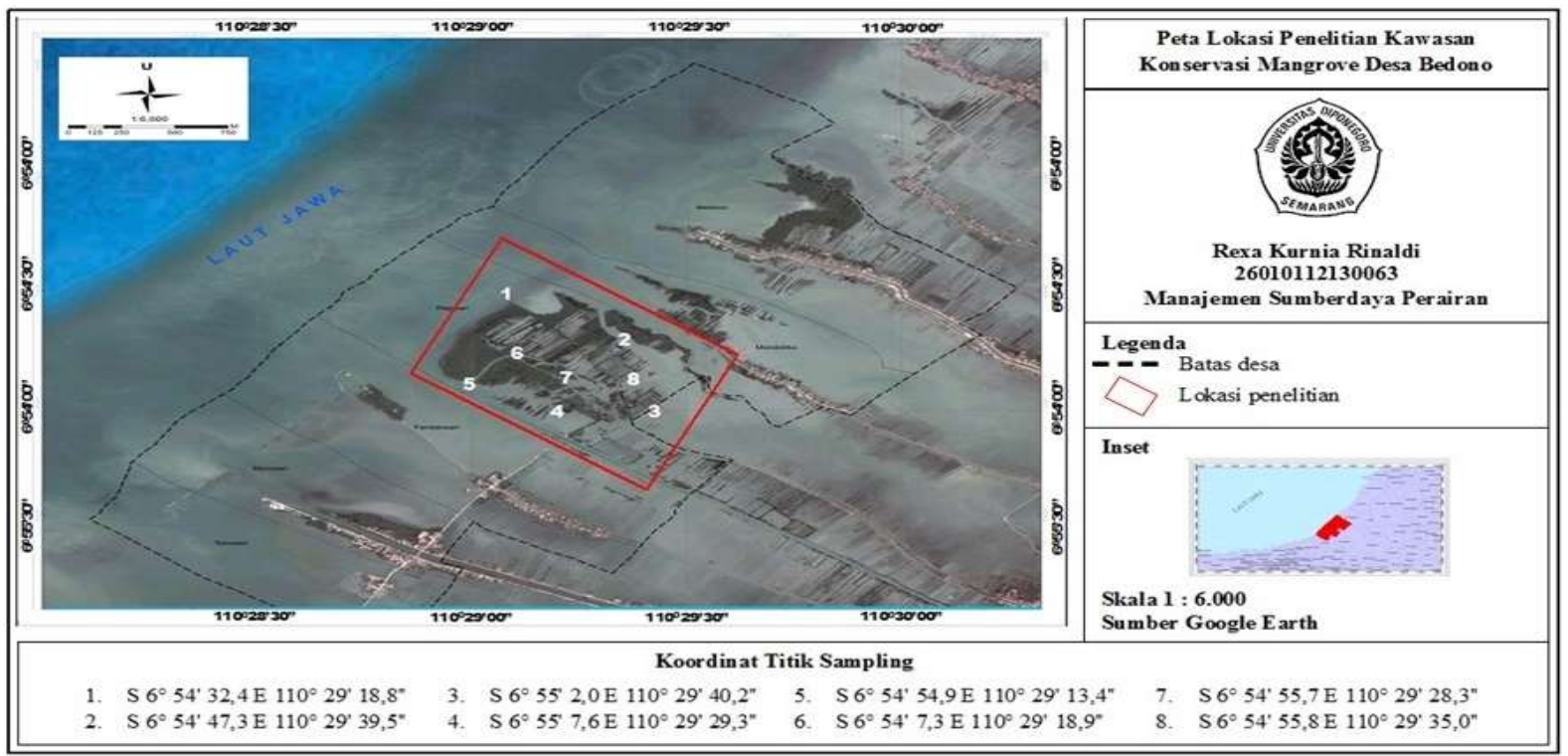

Gambar 2. Peta Lokasi Penelitian

\section{HASIL DAN PEMBAHASAN}

A. HASIL

\section{Komposisi Larva Ikan yang Tertangkap}

Komposisi larva ikan yang tertangkap secara keseluruhan berdasarkan pengulangan pengambilan sampel tersaji pada Tabel 1.

Tabel 1. Komposisi Jenis dan Jumlah Larva Ikan (ind/150m³) yang Tertangkap Tiap Pengambilan Sampel

\begin{tabular}{lcccccc}
\hline \multirow{2}{*}{ No. } & Famili & \multicolumn{2}{c}{ Pengambilan Sampel ke- } & \multicolumn{2}{c}{ Persentase } \\
\cline { 3 - 5 } & & I & II & III & & Jumlah \\
\hline 1 & Mugilidae & 480 & 600 & 40 & 1120 & 5,51 \\
2 & Chanidae & 20 & 0 & 0 & 20 & 0,10 \\
3 & Gerreidae & 60 & 0 & 0 & 60 & 0,30 \\
4 & Apogonidae & 8.080 & 6.680 & 2.600 & 17.360 & 85,43 \\
5 & Scatophagidae & 20 & 0 & 20 & 40 & 0,20 \\
6 & Gobiidae & 120 & 0 & 60 & 180 & 0,89 \\
7 & Belonidae & 0 & 40 & 0 & 40 & 0,20 \\
8 & Ambassidae & 0 & 0 & 20 & 20 & 0,10 \\
9 & Lutjanidae & 0 & 0 & 620 & 620 & 3,05 \\
10 & Engraulidae & 0 & 0 & 60 & 60 & 0,30 \\
11 & Nemipteridae & 40 & 0 & 0 & 40 & 0,20 \\
\hline
\end{tabular}

Sumber : Penelitian 2016

Larva ikan yang tertangkap di Kawasan Konservasi Mangrove Desa Bedono sebanyak 20.320 ind $/ 150 \mathrm{~m}^{3}$ yang terdiri dari 12 famili. Komposisi jenis-jenis larva ikan yang tertangkap adalah Mugilidae, Chanidae, Gerreidae, Apogonidae, Scatophagidae, Gobiidae, Belonidae, Ambassidae, Lutjanidae, Engraulidae, Nemipteridae, dan Oryziatidae. Jenis larva ikan yang paling banyak tertangkap disetiap pengulangan adalah larva ikan apogonidae. Sedangkan jenis larva ikan yang paling sedikit tertangkap di setiap pengulangan adalah larva ikan Chanidae dan Ambassidae. Persentase kemunculan larva ikan yang sering muncul adalah Apogonidae, Mugilidae, Lutjanidae, Oryziatidae. Famili Apogonidae tertangkap disetiap titik dengan persentase kemunculan 85,43\%. Larva ikan yang paling jarang muncul yaitu Famili Chanidae dan Ambassidae dengan persentase kemunculan hanya 0,10\%. 


\section{Pola Distribusi}

Berdasarkan analisis pola distribusi jenis individu dengan indeks morisita, didapatkan hasil bahwa pola distribusi setiap jenis adalah acak. Nilai indeks morisita hasil dari analisis pola distribusi jenis larva ikan yang tertangkap tersaji di Tabel 2.

Tabel 2. Nilai Indeks Morista Jenis Larva Ikan yang Tertangkap di Kawasan Konservasi Mangrove Desa Bedono

\begin{tabular}{cccc}
\hline No. & Famili & Nilai Indeks Morisita & Keterangan \\
\hline 1 & Mugilidae & 0,8308 & Acak \\
2 & Chanidae & 0,9559 & Acak \\
3 & Gerreidae & 0,9853 & Acak \\
4 & Apogonidae & 0,2067 & Acak \\
5 & Scatophagidae & 0,4764 & Acak \\
6 & Gobidae & 0,3032 & Acak \\
7 & Belonidae & 0,9780 & Acak \\
8 & Ambasidae & 0,9559 & Acak \\
9 & Lutjanidae & 0,4636 & Acak \\
10 & Engraulidae & 0,3173 & Acak \\
11 & Nemipteridae & 0,9780 & Acak \\
12 & Oryziatidae & 0,9988 & Acak \\
\hline
\end{tabular}

Sumber : Penelitian 2016

\section{Kelimpahan Larva Ikan}

Hasil perhitungan kelimpahan (ind/150 $\mathrm{m}^{3}$ ) larva ikan dari komposisi larva ikan di Kawasan Konservasi Mangrove Desa Bedono yang ditemukan tersaji di Gambar 3.

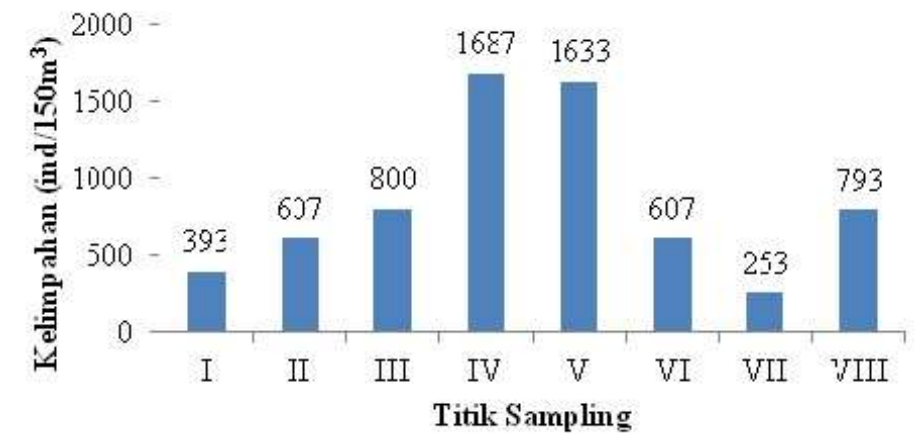

\section{Struktur Komunitas Larva Ikan}

Gambar 3. Kelimpahan Larva Ikan di Kawasan Konservasi Mangrove Desa Bedono

Struktur komunitas yang dihitung meliputi keanekaragaman $\left(\mathrm{H}^{\prime}\right)$, keseragaman (E), dan dominasi (D). Hasil dari perhitungan nilai indeks keanekaragaman, keseragaman, dan dominasi di Kawasan Konservasi Mangrove Desa Bedono tersaji dalam Tabel 3.

Tabel 3. Struktur Komunitas Larva Ikan di Kawasan Konservasi Mangrove Desa Bedono

\begin{tabular}{|c|c|c|c|c|c|c|c|c|c|}
\hline \multirow{2}{*}{ No. } & \multirow{2}{*}{ Struktur Komunitas } & \multicolumn{8}{|c|}{ Titik Pengambilan Sampel } \\
\hline & & I & II & III & IV & $\mathbf{V}$ & VI & VII & VIII \\
\hline 1 & Jumlah spesies & 6 & 4 & 4 & 5 & 2 & 5 & 3 & 4 \\
\hline 2 & Jumlah individu (ind $/ 150 \mathrm{~m}^{3}$ ) & 1.180 & 1.820 & 2.400 & 5.060 & 4.900 & 1.820 & 760 & 2.380 \\
\hline 3 & Indeks Keanekaragaman & 0,599 & 0,362 & 0,144 & 0,182 & 0,027 & 0,942 & 0,857 & 0,182 \\
\hline 4 & Indeks Keseragaman & 0,335 & 0,261 & 0,104 & 0,113 & 0,038 & 0,586 & 0,780 & 0,131 \\
\hline 5 & Indeks Dominasi & 0,752 & 0,836 & 0,951 & 0,938 & 0,992 & 0,443 & 0,457 & 0,934 \\
\hline
\end{tabular}

Sumber : Penelitian 2016

Nilai indeks keanekaragaman di setiap titik pengambilan sampel yaitu lebih kecil dari 1 maka tingkat keanekaragamannya rendah. Nilai indeks keseragaman di titik VII tergolong dalam tingkat keseragaman yang tinggi, nilai indeks keseragaman di titik VI tergolong dalam tingkat keseragaman yang sedang, sedangkan nilai indeks keseragaman di titik I, II, III, IV, V, dan VIII tergolong dalam tingkat keseragaman yang rendah. Nilai indeks dominasi pada titik I, II, III, IV, V, dan VIII tergolong dalam tingkat dominasi yang tinggi, sedangkan pada titik VI dan VII tergolong dalam tingkat dominasi yang rendah. 


\section{Parameter Fisika-Kimia Perairan}

Parameter Fisika-Kimia Perairan yang diukur adalah suhu, pH, salinitas, kecerahan, kedalaman, kecepatan arus. Adapun hasil dari pengukuran Parameter Fisika-Kimia Perairan tersaji dalam Tabel 4. Tabel 4. Hasil Rata-rata 3 Kali Pengulangan Pengukuran Parameter Fisika-Kimia Perairan

\begin{tabular}{|c|c|c|c|c|c|c|c|c|c|}
\hline \multirow{2}{*}{ No. } & \multirow{2}{*}{ Parameter } & \multicolumn{8}{|c|}{ Rata-rata Nilai Titik ke- } \\
\hline & & I & II & III & IV & $\mathbf{V}$ & VI & VII & VIII \\
\hline 1 & Suhu Air $\left({ }^{\circ} \mathrm{C}\right)$ & 30,33 & 31,33 & 30,67 & 31 & 31,67 & 32 & 32,33 & 31,67 \\
\hline 2 & $\mathrm{pH}$ & 6 & 6 & 6 & 6 & 6 & 6 & 6 & 6 \\
\hline 3 & Salinitas $(\%)$ & 30 & 26 & 25 & 23 & 22,33 & 23,33 & 21,33 & 20,33 \\
\hline 4 & Kecerahan & 20,83 & 9 & 15 & 13 & 12,67 & 14 & 12,17 & 10,67 \\
\hline 5 & Kedalaman (cm) & 68,67 & 29,67 & 24,33 & 28,33 & 37 & 43,67 & 32 & 27,67 \\
\hline 6 & Kecepatan Arus (m/s) & 0,11 & 0,13 & 0,05 & 0,11 & 0,09 & 0,1 & 0,03 & 0,07 \\
\hline
\end{tabular}

Sumber : Penelitian 2016

Nilai rata-rata suhu perairan berkisar antara $30,33-32,33^{\circ} \mathrm{C}$, nilai rata-rata $\mathrm{pH}$ perairan yang diperoleh adalah 6 , nilai rata-rata salinitas perairan berkisar antara 20,33 - 30\%, nilai rata-rata kecerahan perairan berkisar antara 9 - 20,83, nilai rata-rata kedalaman perairan berkisar antara $24,33-68,67 \mathrm{~cm}$, serta nilai rata-rata kecepatan arus perairan berkisar antara $0,05-0,13 \mathrm{~m} / \mathrm{s}$.

\section{B. PEMBAHASAN \\ Struktur Komunitas}

Keanekaragaman (H'), keseragaman (E), dan dominansi (D) jenis merupakan kajian indeks yang sering digunakan untuk menduga kondisi suatu lingkungan perairan berdasakan komponen biologis. Kondisi lingkungan suatu perairan dikatakan baik bila diperoleh nilai indeks keanekaragaman (H') dan keseragaman (E) yang tinggi, serta indeks dominansi (D) yang rendah (Hukom, 1999).

Indeks keanekaragaman $\left(\mathrm{H}^{\prime}\right)$ berdasarkan perhitungan pada setiap titik menunjukkan keanekaragaman jumlah populasi dengan nilai yang cukup beragam. Nilai H' tertinggi terdapat pada titik VI dengan nilai 0,942 . Kisaran nilai indeks keanekaragaman (H') pada lokasi penelitian yaitu 0,027 - 0,942 sehingga dapat ditarik kesimpulan bahwa nilai H' larva ikan yang tertangkap selama kegiatan penelitian dapat digolongkan ke dalam keanekaragaman yang rendah. Menurut Odum (1993) dalam Riswandha (2015) bahwa suatu perairan dengan nilai indeks kurang dari $1\left(\mathrm{H}^{\prime}<1\right)$ maka perairan tersebut berada dalam kategori yang mempunyai tingkat keanekaragaman rendah. Menurut Furry, (2011) bahwa suatu komunitas dikatakan mempunyai keanekaragaman spesies tinggi, apabila kelimpahan masing-masing tinggi dan sebaliknya keanekaragaman spesies rendah jika hanya terdapat beberapa spesies yang melimpah.

Berdasarkan hasil perhitungan indeks keseragaman (E) diperoleh kisaran nilai E selama kegiatan penelitian yaitu $0,038-0,780$. Nilai indeks keseragaman pada titik VI dan VII yaitu mendekati 1 sedangkan Nilai indeks keseragaman pada titik I, II, III, IV, V, dan VIII yaitu mendekati 0 . Hal ini menunjukkan bahwa keseragaman pada titik VI dan VII digolongkan ke dalam indeks keseragaman yang sedang dan tinggi sedangkan pada titik I, II, III, IV, V, dan VIII digolongkan ke dalam indeks keseragaman yang rendah. Hal ini diperkuat oleh Pirzan et al. (2005) yang menyatakan bahwa keseragaman yang bernilai kecil atau mendekati nol menggambarkan keseragaman antar spesies di dalam komunitas rendah, sedangkan keseragaman yang bernilai besar atau mendekati satu dapat dikatakan merata atau jumlah individu dalam spesies relatif sama.

Nilai ideks dominasi larva ikan yang diperoleh berdasarkan perhitungan pada setiap titik yaitu berkisar antara 0,443 - 0,992. Nilai indeks dominasi pada titik I, II, III, IV, V, dan VIII memiliki nilai indeks mendekati 1 . Hal ini menunjukkan bahwa tingkat dominasi pada titik-titik tersebut tergolong ke dalam tingkat dominasi yang tinggi. Nilai indeks dominasi pada titik VI dan VII memiliki nilai indeks mendekati 0 . Hal ini menunjukkan bahwa tingkat dominasi pada kedua titik tersebut tergolong ke dalam tingkat dominasi yang rendah. dimana nilai tersebut menggambarkan bahwa pada beberapa titik tidak terdapat jenis larva ikan yang mendominasi dan beberapa titik yang lain terdapat jenis larva ikan yang mendominasi. Menurut Ludwig dan Reynold (1988) dalam Anwar (2008) indeks dominasi memiliki kisaran antara $0-1$. Nilai indeks dominasi yang mendekati 1 menunjukkan bahwa ada satu spesies tertentu yang mendominasi spesies lainnya. Sedangkan nilai yang mendekati 0 menunjukkan bahwa dominasi tidak terjadi dan tidak ada satu spesies tertentu yang mendominasi spesies lainnya.

\section{Komposisi dan Kelimpahan Larva Ikan di Kawasan Konservasi Mangrove Desa Bedono}

Jenis larva ikan yang ditemukan selama penelitian berjumlah $20.320 \mathrm{ind} / 150 \mathrm{~m}^{3}$. Larva ikan terdiri dari 12 famili yang teridentifikasi yaitu Mugilidae, Chanidae, Gerreidae, Apogonidae, Scatophagidae, Gobiidae, Belonidae, Ambassidae, Lutjanidae, Engraulidae, Nemipteridae, dan Oryziatidae. Identifikasi larva ikan yang tertangkap dilakukan sampai tahap famili karena kemampuan serta alat yang digunakan tidak mampu melebihi tahap famili. Cukup banyaknya jumlah larva ikan yang ditemukan di Kawasan Konservasi Mangrove Desa Bedono dikarenakan kawasan mangrove merupakan daerah pemijahan, daerah asuhan, serta tempat mencari makan untuk sebagian biota perairan. Komposisi famili dan kelimpahan larva ikan yang diperoleh pada setiap titik menunjukkan adanya perbedaan. Menurut 
Subiyanto et al. (2008), perbedaan komposisi jenis larva ikan berkaitan dengan migrasi ikan mencari kondisi lingkungan yang sesuai dengan kebutuhan makanan untuk pertumbuhan.

Famili yang paling mendominasi pada lokasi penelitian adalah famili Apogonidae ditemukan di setiap titik. Apogonidae merupakan famili yang tinggal di sekitar ekosistem terumbu karang, serta dapat hidup di berbagai habitat lainnya. Menurut Leis dan Brooke (2000), Apogon lineatus menyenangi substrat pasir dan lumpur sehingga tampak merata kelimpahannya di ekosistem mangrove. Famili Apogonidae merupakan jenis ikan karang yang bermigrasi ke pantai ketika mulai dewasa. Akan tetapi dengan melihat mangrove yang digunakan banyak spesies ikan untuk nursery ground atau daerah perlindungan dan asuhan, maka mungkin saja bila Apogonidae banyak ditemukan (Riswandha, 2015).

Apabila jumlah spesies dan variasi jumlah individu tiap spesies relatif kecil berarti terjadi ketidakseimbangan ekosistem yang disebabkan gangguan atau tekanan dari lingkungan, hal ini menjelaskan bahwa hanya jenis tertentu saja yang dapat bertahan hidup. Jumlah individu yang tidak merata ini berhubungan dengan pola adaptasi masing-masing spesies, seperti tersedianya makanan dan kondisi biologi, fisika, dan kimia perairan lingkungan daerah sekitarnya (Wulandari, 2004).

Sebagian besar larva ikan yang tertangkap pada saat penelitian berada dalam fase post-flexion, dimana pada fase ini bagian tubuh dan organ dalam sudah terbentuk lebih sempurna dibandingkan dengan fase flexion dan mendekati fase juvenile yang memiliki bagian-bagian tubuh yang sudah menyerupai ikan dewasa. Pada fase ini larva ikan juga sudah mampu bergerak karena bagian sirip sudah terbentuk hampir sempurna. Larva ikan yang berada pada fase flexion juga ditemukan pada lokasi penelitian, dimana pada fase ini larva sudah memiliki bentuk yang lebih sempurna dibanding fase pre-flexion. Menurut Helfman et al. (2009), larva ikan pada fase flexion akan bergerak ke perairan yang lebih dangkal seperti daerah terumbu karang, lamun dan mangrove untuk berkembang dan tumbuh.

\section{Distribusi Larva Ikan}

Perbedaan nilai kelimpahan larva ikan pada setiap titik disebabkan oleh kondisi lingkungan setiap titik berbeda. Titik I dengan nilai kelimpahan larva ikan sebesar $393 \mathrm{ind} / 150 \mathrm{~m}^{3}$, hal ini disebabkan titik tersebut tidak hanya dipengaruhi oleh ekosistem mangrove tetapi juga dipengaruhi oleh gelombang air laut. Sedangkan pada titik II,III,VI,dan VIII dengan nilai kelimpahan masing-masing adalah $607 \mathrm{ind} / 150 \mathrm{~m}^{3}, 800 \mathrm{ind} / 150 \mathrm{~m}^{3}, 607 \mathrm{ind} / 150 \mathrm{~m}^{3}, 793$ ind $/ 150 \mathrm{~m}^{3}$. Titik tersebut banyak dipengaruhi ekosistem mangrove tetapi dengan sedikit pengaruh dari masukan perairan terbuka. Titik IV dan V merupakan titik dengan nilai kelimpahan larva ikan tertinggi sebesar $1.687 \mathrm{ind} / 150 \mathrm{~m}^{3}$ dan $1.633 \mathrm{ind} / 150 \mathrm{~m}^{3}$. Kondisi lingkungan pada titik IV dan V tidak hanya dipengaruhi oleh ekosistem mangrove tetapi juga dipengaruhi masukan dari perairan terbuka. Titik VII merupakan titik dengan kelimpahan larva ikan paling sedikit sebesar $253 \mathrm{ind} / 150 \mathrm{~m}^{3}$. Hal ini disebabkan titik tersebut hanya di pengaruhi oleh ekosistem mangrove karena tidak mendapat masukan dari perairan terbuka secara langsung. Sedimentasi yang menyebabkan pendangkalan pada titik tersebut juga dapat mempengaruhi kelimpahan larva ikan dimana larva ikan kekurangan ruang untuk bergerak. Menurut Nagelkerken (1981) dalam Anwar (2008) kedalaman bukan merupakan faktor pembatas bagi distribusi vertikal ikan, tetapi habitat yang sesuai memegang peranan yang penting bagi keberadaan suatu jenis. dikemukakan juga bahwa pada daerah yang terbuka atau yang terlindung mendapat masukan jenis dan jumlah larva ikan yang sama, tetapi karena adanya perbedaan tipe habitat maka pada akhirnya jenis larva yang dapat bertahan menjadi berbeda.

Pola penyebaran biota dipengaruhi oleh tipe habitat yang meliputi parameter fisika kimia perairan serta makanan dan kemampuan adaptasi dari suatu biota dalam suatu ekosistem (Alfitriatussulus, 2003). Berdasarkan analisis indeks morisita, pola distribusi larva ikan di Kawasan Konservasi Mangrove Desa Bedono menyebar secara acak. Dengan demikian setiap famili memiliki tingkat toleransi terhadap lingkungan yang cukup tinggi. Pola distribusi secara acak disebabkan oleh beberapa faktor, antara lain kondisi lingkungan, tipe substrat serta kebiasaan makan dan cara mereka berproduksi (Risawati, 2002 dalam Alfitriatussulus 2003). Penyebaran bersifat acak berarti keberadaan spesies tidak memiliki kecenderungan untuk hidup berkoloni dan dapat bertahan hidup di mana saja pada suatu ekosistem. Pola penyebaran acak juga terjadi karena adanya persaingan yang positif antar individu, sehingga akan mendorong terbentuknya pembagian ruang diantara individu-individu tersebut.

Jumlah larva ikan selama pengambilan sampel disetiap titik selalu berfluktuasi. Hal ini berkaitan dengan migrasi ikan mencari kondisi lingkungan yang sesuai dan kebutuhan makanan untuk pertumbuhannya. Selain itu karena dipengaruhi pasang surut yang mendistribusikan larva ikan keberbagai habitat. Menurut Odum (1971) dalam Genisa (2000) menjelaskan bahwa biota yang hidup di daerah estuari adalah biota yang mempunyai toleransi yang tinggi terhadap perubahan lingkungan, yang ditandai dengan jumlah jenis sedikit dan potensi yang tinggi. Estuari adalah suatu tempat pertemuan antara air tawar dan air laut. Habitat ini lebih subur dan produktif sehingga daerah ini sering dijadikan sebagai daerah asuhan bagi anak-anak ikan. Salah satu estuari adalah muara sungai yang selalu dipengaruhi oleh pasang surut dan salinitas yang berfluktuasi, yang mempengaruhi mempengaruhi bentuk kehidupan biota di daerah tersebut.

\section{KESIMPULAN}

Kesimpulan yang diperoleh dari penelitian ini adalah sebagai berikut:

1. Jenis larva ikan yang ditemukan selama penelitian di Kawasan Konservasi Mangrove Dusun Senik Desa Bedono Kecamatan Sayung Demak berjumlah 20.320 ind $/ 150 \mathrm{~m}^{3}$ terdiri dari 12 famili yang teridentifikasi yaitu Mugillidae, Chanidae, Gerreidae, Apogonidae, Scatophagidae, Gobiidae, Belonidae, Ambassidae, Lutjanidae, Engraulidae, Nemipteridae, dan Oryziatidae. Larva ikan Apogonidae merupakan yang paling banyak tertangkap 
dengan jumlah $17.360 \mathrm{ind} / 150 \mathrm{~m}^{3}$ karena larva ikan Apogonidae menyenangi substrat belumpur dan sesuai dengan ekosistem mangrove. Sedangkan larva ikan Chanidae dan Ambassidae merupakan yang paling sedikit tertangkap yaitu sebesar $20 \mathrm{ind} / 150 \mathrm{~m}^{3}$.

2. Pola penyebaran larva ikan berdasarkan indeks morisita menyebar secara acak. Penyebaran bersifat acak berarti keberadaan spesies tidak memiliki kecenderungan untuk hidup berkoloni dan dapat bertahan hidup di mana saja pada suatu ekosistem.

\section{UCAPAN TERIMAKASIH}

Penulis menyampaikan ucapan terimakasih kepada Ir. Anhar Solichin, M.Si yang telah membantu dan memberikan bimbingan dalam penelitian serta semua pihak yang telah membantu terlaksananya penelitian sampai dengan selesai

\section{DAFTAR PUSTAKA}

Alfitriatussulus. 2003. Sebaran moluska (bivalvia dan gastropoda) di muara sungai Cimandiri, Teluk pelabuhan Ratu, Sukabumi, Jawa Barat [Skripsi]. Program Studi Manajemen Sumberdaya Perairan, Fakultas Perikanan dan Ilmu Kelautan, Intitut Pertanian Bogor.

Anwar N. 2008. Karakteristik fisika kimia perairan dan kaitannya dengan distribusi serta kelimpahan larva ikan di Teluk Palabuhanratu [Tesis]. Sekolah Pascasarjana, Institut Pertanian Bogor.

Furry, N. R. 2011. Jenis, Kelimpahan, dan Distribusi Larva dan Juvenil Ikan di Muara Sungai Cimaja dan Citiis, Teluk Palabuhanratu, Kabupaten Sukabumi, Jawa Barat [Skripsi]. Bogor : Menejemen Sumberdaya Perairan, Fakultas Perikanan dan Ilmu kelautan, Institut Pertanian Bogor

Genisa, A. S. 2000. Kekayaan jenis ikan-ikan dasar di Muara Sungai Mamberamo, Irian Jaya. Balitbang Biologi Laut. Oseanologi LIPI. Jakarta.

Gulo, W. 2002. Metode Penelitian. Jakarta: PT. Grasindo.

Helfman, G., B. B. Collete, D. E. Facey, B. W. Bowen. 2009. The Diversity of Fishes Biology, Evolution, and Ecology. Wiley-Blackwell, UK. $740 \mathrm{hlm}$.

Hukom FD. 1999. Ekostruktur dan distribusi spasial ikan karang (famili Labridae) di perairan Teluk Ambon. Pros. Lok. Pengelolaan dan Iptek Terumbu Karang Indonesia. Jakarta.

Leis, J. M., dan C. E. Brooke. 2000. The Larvae of Indo-Pacific Coastal Fishes: An Identification Guide to Marine Fish Larvae. Fauna Malesiana; Vol.2. Leiden;Boston;Koln. Brill. 850 hlm.

Nazir, M. 1988. Metode Penelitian. Ghalia Indonesia, Jakarta.

Olii AH. 2003. Kajian faktor fisik yang mempengaruhi distribusi ichthyoplankton (awal daur hidup ikan). Jurnal. Pengantar Falsafah Sains. Program Pascasarjana/ S3, Institut Pertanian Bogor.

Pirzan, A.M., Utojo, M. Atmomarso, M. Tjaronge, A.M. Tangko, dan Hasnawi. 2005. Potensi lahan budi daya tambak dan laut di Kabupaten Minahasa, Sulawesi Utara. Jurnal Penelitian Perikanan Indonesia 11 (5): 43-50.

Prianto, E., S. Nurdawaty, dan M. M. Kamal. 2013. Distribusi, Kelimpahan dan Variasi Ukuran Larva Ikan di Estuari Sungai Musi. BAWAL., 5(2):73 - 79.

Redjeki, S. 2013. Komposisi Dan Kelimpahan Ikan Di Ekosistem Mangrove Di Kedungmalang, Jepara. Jurnal Ilmu Kelautan 18(1):54-60. Issn: 0853-7291. Jurusan Ilmu Kelautan, Fakultas Perikanan dan Ilmu Kelautan Universitas Diponegoro. Semarang

Riswandha, N. S., A. Solichin, dan N. Afiati. 2015. Struktur Komunitas Larva Ikan pada Ekosistem Mangrove dengan Umur Vegetasi yang Berbeda di Desa Timbulsloko, Demak. Journal Of Maquares 4 (4):164-173. Jurusan Perikanan, Fakultas Perikanan dan Ilmu Kelautan Universitas Diponegoro. Semarang

Subiyanto, Ruswahyuni dan D. G. Cahyono. 2008. Komposisi Dan Distribusi Larva Ikan Pelagis Di Estuaria Pelawangan Timur, Segara Anakan, Cilacap. Jurnal Saintek Perikanan Vol. 4(1): 62 - 68. Universitas Diponegoro. Semarang.

Wulandari, Yeni. 2004. Studi Keterkaitan Kelimpahan Post Larva Ikan dengan Habitatnya pada Ekosistem Padang Lamun Sebelah Timur di Perairan Pulau Tidung Besar, Kepulauan Seribu, Jakarta Utara. [Skripsi]. Institut Pertanian Bogor, Bogor, $107 \mathrm{hlm}$. 